\title{
Information Technology in Norwegian education - consistency of strategic initiatives for implementing IT in primary education
}

\author{
Sindre Røsvik \\ Educational Director, Giske Kommune \\ Øvre Nordstrand, $N$ - 6050 Valderøy, Norway \\ Tele + 47701820 05; Fax + 4770181286 \\ E-mail: sindre@mimer.no
}

\begin{abstract}
In August 1997 Norway started implementing a major school reform - Reform '97, a multiple reform on childhood, family, culture and education. Reform ' 97 is part of an overall educational reform from kindergarten to university, remaking the structure and content of education in primary and lower secondary school. Information Technology and its implications are focused as important elements of the educational reforms, mainly on content but to some degree on structure as well. Goals and means of IT in Norwegian educational policy include national plans for IT, new curriculum guidelines, methodological guides on subjects and competence-building plans. Consistency between national IT plans, the curriculum L97 and plans introduced to implement the reform are a major part of the national initiative. The effect of these plans, especially on IT, can be questioned because of the financial arrangements and diverse plans for assigning responsibility.
\end{abstract}

\section{Keywords}

Curriculum development, competencies, national policies, elementary education, secondary education, higher education

Capacity Building for IT in Education in Developing Countries

G. Marshall \& M. Ruohonen (Eds.)

(1) 1998 IFIP. Published by Chapman \& Hall 


\section{INTRODUCTION}

After a period of intensive national experiments and projects from the mid 1980s onward Norway experienced some years of vacuum in the national efforts to support and promote use of Information and Communication Technologies (ICT). Some main national projects had failed and the political climate did not favour putting money into new initiatives.

During the 1990s education has been given substantial publicity and priority. From 1994 onward there has been an educational reform for upper secondary education, and, from August 1997, Reform ' 97 has focused on primary and lower secondary schools. Such comprehensive reforms are changing both the structure and content of the Norwegian education system. New curriculum guidelines (L97) are the most substantial elements of Reform '97. Competence-building programmes are being run to ensure the implementation of the curriculum.

Mass media and meetings have been used to introduce Reform '97 to students, parents and local authorities. It is emphasised that this is a major and comprehensive reform, changing not only structure and curriculum, but also ways of learning and working in schools, ways of evaluating students' work, grading, exams and other aspects of education. New learning materials have been introduced to all students in all subjects.

In this discussion our focus will be on national ICT initiatives and how they are dealt with in the national curriculum. The intention is to see if the different plans form a consistent strategy on ICT in primary education.

\section{MAIN ELEMENTS OF NATIONAL PLANS ON ICT IN EDUCATION}

During recent years ICT in education has been a part of a general public interest in technology. Elaboration of policy papers and debates have kept the level of attention high, with many questions being raised about implementation of the ICT policies given the lack of financing.

In 1995 the Norwegian plan,coordinated by The Ministry of Transport, set an agenda of challenges to deal with ICT. The report includes a chapter about the global local school, the importance of learning to use ICT and the use of ICT in learning. The report stresses the role of education in a modern society, the importance of mastering ICT and educational possibilities offered by ICT.

Following the general strategy document, the Ministry of Education elaborated plans for ICT in Norwegian Education through A Plan for 1996-1999 (Royal Ministry of Education, Research and Church Affairs, 1996).

A key formulation of the new directives is that teachers and students are to be personal users of ICT capable of using ICT in those parts of their learning to which ICT can add value. It is also expected that the students and teachers have the necessary grounding for making use of ICT at work and in their leisure time.

A main element of the plan is to clarify responsibilities of different levels, from the national to the classroom level. The national level covers the development of curriculum, a methodological guide and authorisation of learning material. Development of competence programmes is also a national responsibility and the 
plan includes initiatives to enable universities and teacher colleges to run programmes. School owners are to organise the implementation of the curriculum, competence building programmes, financing and other aspects of ICT use. Teachers and students are recognised as those who will finally implement the curriculum. To succeed they need support of different kinds.

The plan advocates main approaches for ICT use in schools: 'using to learn'; 'learning to use'; teacher training; and technical infrastructure and organisation. A plan of action is formulated through 31 different initiatives, or measures, mostly on using to learn (15 initiatives), while the rest of the measures are focused on learning to use, teacher training, technical conditions and organisation.

\section{1 'Using to learn'}

Information Technology in Norwegian education emphasises the integration of technology, without giving undue weight to technology. Instead the plan stresses ICT as a learning aid to support the learning process. ICT is to be used as a source of information and communication, to develop teaching and training methods, and to make different kinds of information collections. Relevant Norwegian information - texts, speeches, pictures, and other types of data - should be available to schools. Research and development projects must be run to offer new insights into the learning process. The importance of a lifelong perspective on learning and the greater opportunities offered by ICT as well as the establishment of new learning environments are underlined by the plan.

Such a plan challenges Norwegian mediators, publishers, libraries, broadcasters, software companies and other software manufacturers to develop and process information, and make it available to the educational sector.

\section{2 'Learning to use'}

Learning to use means getting familiar with and mastering ICT. From the first years of schooling it means playing with the computer, getting used to the keyboard and other devices. From the middle and upper level of primary school it means learning to use standard software.

According to the plan, learning to use ICT should be integrated into each subject to prepare for general use in studies and occupations. Courses should be introduced at the different levels to suit students' different needs, and to ensure opportunities for coherent and structured ICT training to adults.

\subsection{Teacher training}

Teacher training initiatives cover future education and refresher courses in ICT for teachers, the place of ICT in teacher training, the boosting of the competence of teachers training teachers, and research and development relating to the use of ICT .

A bottleneck in the implementation of the measures is a lack of competence in the implementing institutions. This has been an acknowledged problem but possible solutions are to buy or employ the needed competence along with upgrading the teacher training staff. 


\subsection{Technical infrastructure}

The main initiatives under this measure are to consider establishment of a comprehensive electronic network for Norway's entire educational sector. Easing access to national and international data networks has been given priority. Software agreements will secure efficient and reasonable prices.

\subsection{Organisation}

Organisation deals with implementation of the plan as well as new ways of organising teaching and training as a consequence of introducing the use of ICT. Administrative possibilities opened by use of ICT are also dealt with.

Accompanying the plan are yearly action plans, dependent on budgets designed to realise the plan. The Ministry of Education has also conveyed questionnaires to follow the implementation of the plan in the schools, to check ICT investments and to provide other forms of monitoring.

Main elements of the reforms are to develop a more holistic school system by strengthening the structures of education and by focusing on the content of education. The reforms also stress the importance of education in a modern society, both to the benefit of each individual and to society as a whole. Content and quality are emphasised in the reforms to raise motivation and to generate attention to users' ability to require new knowledge.

Objectives of the government can be summarised as:

- equal access to education and training for all independent of gender, ethnic origin, geographical, social background or disability;

- a belief that education should motivate all to acquire knowledge as a lifelong perspective;

- a belief that the content of Norwegian education must be of high quality in order to respond to the needs and requirements of the international community, and promote innovation.

Education and training are to be considered as part of a lifelong process, a continuing process on the part of individuals and organisations. Growing globalisation is also reflected in the reforms and the educational policy documents.

The new curriculum (L97) consists of three main parts. The first general part is common to primary, secondary and adult education. The second part describes principles and guidelines for primary and lower secondary education. The final part presents syllabi of subjects.

\subsection{General part of $\mathrm{L} 97$}

The general part of the plan provides a holistic vision of education by drawing on seven perspectives:

- the spiritual human being - basic values, cultural heritage and identity; 
- the creative human being - creative abilities and creativity;

- the working human being - versatile and practical ability;

- the literally-educated human being - basic knowledge and general education;

- the social human being - cooperation and independence;

- the environmentally aware human being - nature, environment and technology.

Summing up all perspectives and values, education shall stimulate the development of the human as a whole to produce the integrated human.

\subsection{Principles and guidelines for primary education}

This section of the plan presents values and principles of the comprehensive school, balancing and focusing on community and individual adjustments, upbringing and learning environment, home and school, school and local community, cooperation within school, and local developmental work. It also explains the construction of the syllabi, content and structure, local planning of the syllabi for each subject and the organisation of the content into themes. Characteristics of the main levels - lower primary, upper primary and lower secondary - are underlined, and important ways of working, the use of different learning materials and evaluation strategies are presented.

\subsection{Syllabi of subjects}

The syllabus for each subject is divided into three parts, consisting of an introduction to the subject as part of a whole, ways of working and structure of the subject. Then there are main goals of the subject, goals of the levels (1-4, 5-7 and 8-10 classes) and, finally, the main elements of each class from class 1 to 10 .

Until now curriculum guidelines in Norway have had the status of guiding frameworks for education. They only indicate the content and direction of teaching and upbringing. The local school authorities and, not least the teacher, could, to a great extent, decide what and how to teach. Main textbooks were authorised by national bodies. With national-elaborated exams and educational traditions the reality was that we had a standard national education plan.

L97 is changing the guiding status of the national curriculum. The consequence is that when L97 says that education will make sure that the students develop knowledge about, and insights and attitudes on, the development of the Information Society and Information Technology (L97) this must be done in order to fulfil the curriculum. If plans are not carried out, schools or municipalities can be sued by students or parents.

To understand the way L97 is designed and is supposed to work more details will be presented. The role of ICT, or ICT as conceived in L97, will be commented on along with a presentation of the curriculum. 


\section{AN OVERVIEW OF THE CURRICULUM AND THE ROLE OF ICT}

ICT is to be integrated into all subjects through the new subject syllabi. New textbooks in every subject will include ICT, and some of the books contain multimedia CD-ROMs or other electronic learning materials. There are also references to Internet in texts and exercises.

The preface of L97 says the intent of the ICT curriculum have to be implemented gradually and that implementation should be adjusted to what is possible economically for municipalities - the school owners. It has been indicated that the place and significance of ICT in the guidelines was planned to be stronger but the Ministry of Finances found the plan to be too expensive. Educational gains were adjusted to economical realities. The result was that throughout the text plans for the use of ICT were modified. However use of ICT is obligatory in spite of the comments in the preface.

Reading L97 carefully we will find that ICT is not specifically mentioned in the general part. Technology is, but not ICT. The next part, on principles and guidelines, is included in the syllabus on the subjects - society and contemporary time, for example, where ICT is mentioned as an example of cross-curricular knowledge areas. A chapter about learning materials, for example, includes a discussion of ICT.

There are many statements that indirectly underpin the use of ICT. The most important sentence in this context, in my opinion, is the one stating that we shall prepare the students, making them able to cope with challenges in a rapidly changing world. It says the education will qualify people for productive participation in today's labour force and supply the basis for later shifts in occupations as yet not envisaged (L97).

\subsection{Curriculum 97 - Syllabi}

The elements of ICT are not strikingly emphasised in the syllabi but ICT is mentioned as an important part of the educational process that ought to be integrated, when useful, as a tool or learning aid. Using ICT to learn and learning to use ICT are included in the syllabi from the first years by directing that learning by playing should be an important part of schooling till the lower secondary level, when different kinds of software are to be introduced as well as use of Internet.

When goals and aims of the subjects are stated, ICT is included in discussions of the Norwegian, English, mathematics, nature and environment, and social science subjects. In discussions of ways of working, ICT is also mentioned. At the different levels use of ICT is described. Examples of selected curricular topics include:.

- Goals at the lowest levels 1-4 classes (6-9 year olds)

- Norwegian: The students will be confident users of ICT .

- Mathematics: The students will be confident about simple use of electronic learning aids.

- Goals of the 2 class - 7 years old

- Norwegian: Students will play on the computer, and write and draw. 
- English: Students will read and write at their own pace by using text with pictures, and play with English software.

- Mathematics: Students will experiment with numbers and symbols, examine methods of arithmetical operations and do calculations using a calculator and software.

- Social science: Students will work with and discuss impressions and experiences gathered from magazines and comics, radio and television, video and computer networks.

- Goals at the lower secondary levels - 8-10 classes (13-15 year olds)

- Norwegian: Students will be able to search for information using all kinds of information sources such as the library, archives and ICT, and will learn to use the sources critically and individually in their own work. They will know different media, and how different media make it possible to communicate orally and by written texts. Students will be able to evaluate the impact media has on the individual and the society.

- Art and crafts: Students will be able to use different techniques of photo, ICT and video, and reflect on use of symbols and massmedia's visual messages.

Most of the subjects include similar descriptions of ways to use ICT at different grade levels.

\section{COMPETENCE-BUILDING PROGRAMMES TO FULFIL L97}

To make the new curriculum a reality in the classes every teacher is offered courses in one or more subjects. Courses emphasise new topics, ways of working/learning and other aspects of ICT use. Efforts are made to ensure that all teachers use crosscurricular ways of organising the syllabus. Teachers must also ensure that students work in cooperative learning situations throughout the planning and implementation of projects. ICT is supposed to be part of all subjects and working with projects should be integrated into instruction as a natural part of all subjects.

\subsection{Competence building on ICT to support L97}

The Ministry of Education has made an in-service training plan for ICT. The introduction states that L97 emphasises the need to meet the challenge of ICT and says that many teachers are personal users of ICT. The teachers are supposed to use ICT in their personal administrative work and in preparations for lessons.

The plan says that ICT is to be used as a integrated tool in learning, when useful to the learning process of the students. The plan also points out that ICT can open new ways of working and learning, and new areas of knowledge - especially in work on projects. A major statement in L97 says that ICT can be used for word processing in order to help students prepare for projects (brainstorming), in planning the project (formulating the goals of learning), in running the project 
(searching information, finishing and presenting the product), and in evaluating the projects. The plan says use of ICT can promote student-centred learning.

The plan says that at all levels adequate software should be used and that teachers must be familiar with the meaning of the terms 'use to learn', 'learn to use' and 'play to learn'. The aim of the courses will make the teachers reflective didactic users of ICT when planning and implementing classes. An important part of the courses is the new role of the teacher as facilitator, guide, advisor and team leader.

The teacher training programmes can be conducted as integrated parts of formal university grades, raising the importance of the courses and the significance of acquired knowledge, skills and salaries. The entire staff of schools can participate in order to strengthen the usefulness of the courses. Main goals of the in-service training are to make the teachers :

- become personal computer-users;

- be able to use ICT in education;

- develop reflective attitudes on use of ICT in education;

- be able to make use of ICT in personal competence development.

The plan also says that ICT users will know the relevant educational software for their subjects, know how the software can be used in learning activities and know the possibilities for the educational use of Internet.

According to the plan, to be a reflective ICT user it is necessary to be familiar with the experiences of others. Internet can provide access to educational networks and conferences. It is also recommended that homepages of schools be downloaded and discussed - both in teachers' own schools and on-line. Participation at ICT conferences is also viewed as useful.

To develop reflective attitudes the plan recognises that it is important to be aware of the possibilities and weaknesses of ICT, including ethical dilemmas in using ICT, legal laws and rights.

The plan also considers that it is important for teachers to become aware of the possibilities of using ICT in individualised adapted education, and for minority groups and students with special needs. Special equipment, switches and software developed for special needs should be known by teachers. For example, Internet offers new possibilities for language minorities to get in touch with their own language and culture by the World Wide Web.

A reflective ICT attitude also means being aware of and using new ways of organising and working in the classroom, both when learning to use ICT and using ICT to learn.

For courses to have the desired effect it is necessary to have access to a computer and time to get experience in using it. Self-instructing books/courses can be used in addition to the courses. The training then can alternate between instruction, selftraining and new instruction. Exercises and tasks during the course can be related to the job.

Additional educational experience can be planned and run by mapping the participants' competence - offering basic modules for those in need and then mapping their level before going into more specialised courses related to their subjects and level of schooling. Finally, more advanced courses can be offered. 
It is considered positive for teachers to use the equipment available at their schools and to group colleagues in networks. More advanced users on the staff can be guides to their colleagues. In this way experience developed through the courses will be more easily accessible later. Specialists can be engaged from outside the school for special purposes. PLANS, CURRICULUM 97 AND PRACTICAL POLICY

There are comprehensive efforts to implement ICT in education in Norway nowadays. According to the national ICT plans, the new curriculum L97 and the supporting competence-building programmes for the use of ICT will be fully integrated to education by using ICT in the learning process, and in learning to use ICT.

There is a public focus and discussion on how to ensure equal opportunities and access to ICT in every classroom. No doubt great differences exist among schools and teachers, both for access to ICT and for readiness to use ICT. So even if there is some consistency between different national plans on ICT, the challenge in implementing ICT is to make every teacher and student personal users of ICT, and to make ICT an additional value for teaching and learning. The major bottleneck to the plan is access to computers.

It can also be questioned if the curriculum formulations on ICT will be considered obligatory by schools and teachers. It is likely that there will be continuously different levels in budgeting of ICT by school owners. This problem can be addressed by more national initiatives, financial support and/or more outspoken demands. Then, no doubt, the initiatives will be more effective. When access to ICT is solved in a proper way competence building can successfully support implementation of ICT to increase students' learning processes and society's need for competent citizens.

Reform ' 97 certainly does integrate ICT into the curriculum in a more pervasive way than previous plans. ICT is penetrating every subject and is supposed to be used as a tool where and when useful. Actions are taken, or planned, to make sure that ICT will be a real part of the curriculum by supporting national software development, by integrating ICT into standard learning materials, by offering ICT module courses and by integrating the use of ICT in the different subject areas.

So far though, the most obvious obstacle has not been dealt with in a proper way. Teachers' and students' access to computers is still poor. There are big differences from school to school and municipality to municipality, but mainly there is an overall lack of computers, not to say multimedia computers with Internet access.

If we are to cope with the challenges of the rapidly changing society and make use of new opportunities offered by ICT, plans have to be realised by giving teachers and students access to necessary equipment. If budgets do not include these resources, national plans and curricula will not be fulfilled, or may only be 
partly fulfilled. Only when schools have the needed amount of ICT equipment can competence building be successful. The most important competence building in this field is the development of pedagogical methods. That only can happen when long-term competence programmes can work along with real-life experiences where teachers and students are using computers in daily work and daily learning processes.

\section{REFERENCES}

The Royal Ministry of Education, Research and Church Affairs. (1996) IT in Norwegian Education. A plan for 1996-1999. ( F 4033, English version). Ministry of Education, Oslo, Norway.

The main documents of Reform' 97, some in English, are available on Internet: http://odin.dep.no/kuf/

\section{BIOGRAPHY}

Sindre Røsvik has been chairman of the Norwegian Educational Computer Society (NPD) since 1987 and a member of IFIP's Working Group 3.5 (primary education) since 1987. Director of education in Giske municipality, Norway, he has over a range of years been actively organising courses on the educational use of IT, has presented papers at conferences and contributed to national IT plans through written contributions. 